УДК 796.894:378

\title{
ВАЛЕРІЙ ЖАМАРДІЙ
}

Вищий державний навчальний заклад України «Українська медична стоматологічна академія», м. Полтава

\section{ОСОБЛИВОСТІ СОЦІАЛЬНО-ПСИХОЛОГІЧНОЇ АДАПТАЦІЇ СТУДЕНТІВ- ПЕРШОКУРСНИКІВ ДО НАВЧАЛЬНО-ТРЕНУВАЛЬНОЇ ДІЯЛЬНОСТІ 3 ВИКОРИСТАННЯМ ЗАСОБІВ ФІТНЕСУ}

Розглядається проблема соціально-психологічної адаптації студентів-першокурсників до навчально-тренувальної діяльності 3 використанням засобів фітнесу. 3'ясовано, що поняття соціально-психологічної адаптації можна розглядати як процес пристосування студентівпершокурсників до нових умов навчально-тренувальної діяльності у закладі вищої педагогічної освіти, входження у фізкультурно-освітнє середовище, засвоєння його норм, вироблення моделі поведінки та навчально-тренувальної діяльності. Визначено, що соціально-психологічна адаптація студентів-першокурсників на початкових етапах навчально-тренувальної діяльності обумовлена рядом закономірних особливостей і характеризується великим обсягом матеріалу, високою самостійністю і відповідальністю. Найбільші складнощі полягають у зміні соціальної позиції студентів-першокурсників під час переходу зі шкільного соціуму, методів і засобів навчальнотренувальної діяльності, взаємозв'язків, відносин і стереотипів поведінки. Доведено, що одним із найбільш ефективних організаційних механізмів забезпечення успішної адаптації студентівпершокурсників до навчально-тренувальної діяльності 3 використанням засобів фітнесу $\epsilon$ соціально-психологічна адаптація, яка об’єднує зусилля викладачів із фізичного виховання. Основними формами навчально-тренувальної діяльності мають стати тренінги, круглі столи, залучення студентів-першокурсників до активної навчально-тренувальної та змагальної діяльності під час навчання у закладі вищої педагогічної освіти.

Ключові слова: адаптація, вікові особливості, навчально-тренувальна діяльність, студентипершокурсники, фізичне виховання, фітнес, фітнес-технології.

Постановка проблеми. Соціально-економічні перетворення, які відбуваються у всіх сферах суспільного життя, розвиток інноваційних технологій визначають необхідність випереджаючого розвитку системи вищої педагогічної освіти на засадах гуманізації та інтенсифікації навчально-виховного процесу з фізичного виховання. На перший план висуваються питання підвищення ефективності навчальних занять із фізичного виховання студентів у педагогічних закладах вищої освіти з точки зору своєчасного задоволення потреб студентської молоді. Інтенсифікація навчально-виховного процесу 3 фізичного виховання пролонговує необхідність повноцінного включення студентів у навчально-тренувальну діяльність на всіх курсах навчання. Початковий період навчально-тренувальної діяльності характеризується складністю, важливістю особистісного становлення майбутнього фахівця. Навчально-виховний процес із фізичного виховання студентів-першокурсників здійснюється без урахування особливостей соціально-психологічної адаптації до навчально-тренувальної діяльності з використанням засобів фітнесу. Вирішення цієї проблеми нерозривно пов'язане з необхідністю цілеспрямовано-організованого, педагогічного сприяння, виявлення педагогічних умов, реалізація яких дозволить оптимізувати навчально-виховний процес із фізичного виховання, адаптацію студентів-першокурсників до навчально-тренувальної діяльності, розвитку фітнес-технологій.

Аналіз досліджень і публікацій. Загальні проблеми педагогічного забезпечення навчально-виховного процесу з фізичного виховання розглянуто у наукових дослідженнях (В.М. Завійська (2015); С.М. Канішевський (1997); Н.I. Мачинська (2012); C.I. Присяжнюк (2008); О.Г. Сущенко (2010); О.А. Томенко (2012)). Особливості соціально-психологічної адаптації студентів-першокурсників до навчально-тренувальної діяльності, зокрема 3 використанням засобів фітнесу розглядали В.В.Білецька (2013); М.М.Булатова (2007), В.І. Григорьєв (2006); В.Б. Зінченко (2011); Л.Я. Іващенко (2008); О.Я. Кібальник (2007); Т.Ю. Круцевич (2010); О.Г. Сайкіна (2009); I.A. Усатова (2014). Окремі наукові праці присвячені адаптації студентів до навчання у вищих навчальних закладах (В.П. Андрущенко (2011); $\quad$ Ю.О. Бохонкова (2011); $\quad$ А.О.Жиденко (2012); .П. Левківська (2001); О.В. Плотнікова (2001)). Аналіз навчально-методичної літератури засвідчує, що особливості соціальнопсихологічної адаптації студентів-першокурсників до навчально-тренувальної діяльності з використанням засобів фітнесу ще не стали предметом комплексного наукового педагогічного дослідження. 
Мета статті полягає у визначенні особливостей соціально-психологічної адаптації студентівпершокурсників до навчально-тренувальної діяльності з використанням засобів фітнесу.

Виклад основного матеріалу. Соціально-психологічна адаптація студентів-першокурсників до навчально-тренувальної діяльності $€$ одним із найскладніших соціально-психологічних феноменів. Вона визначає характер, мотивацію і спрямованість навчально-тренувальної діяльності студентів на старших курсах і після закінчення закладу вищої педагогічної освіти. Така ситуація зумовлює необхідність розгляду особливостей адаптаційного періоду студентів-першокурсників до навчально-тренувальної діяльності 3 використанням засобів фітнесу.

Розуміння особливостей соціально-психологічної адаптації безпосередньо залежить від середовища, в якому перебувають студенти під час навчання у закладі вищої педагогічної освіти. Студенту-першокурснику доводиться проходити декілька важливих етапів адаптації:

а) дидактичну адаптацію - пристосування до характеру, змісту, структури та умов організації навчальновиховного процесу з фізичного виховання, розвиток спеціальних умінь і навичок самостійної навчальної та навчально-тренувальної діяльності;

б) соціально-психологічну (суспільну) адаптацію - пристосування до нового освітнього середовища, навчального колективу, його звичаїв, традицій, умов побуту, нових форм студентської культури, використання вільного часу, особливостей самостійного життя;

в) професійну (формальну) адаптацію - вироблення нового ставлення до професії, засвоєння навчальних форм, оцінок, способів і прийомів самостійної роботи, формування нових видів навчально-тренувальної діяльності (Левківська, 2001; Carter, 1982).

Успішна адаптація студентів-першокурсників до навчально-тренувальної діяльності й оволодіння фітнестехнологіями є складовою гармонійного розвитку кожного студента як особистості, майбутнього фахівця. Адаптаційний період, який починається з перших днів навчання є дуже важливим етапом, оскільки у цей час відбувається "активне, творче пристосування студентів до умов вищої школи, в процесі якого формуються оптимальні взаємини, покликання до обраної професії, раціональний колективний режим праці та побуту” (Плотнікова, 2001).

Соціально-психологічна адаптація студентів-першокурсників до навчально-тренувальної діяльності $\epsilon$ найважливішою складовою навчально-виховного процесу з фізичного виховання. Вона не $є$ лише пасивним відображенням дійсності, своєрідним віддзеркаленням соціальних-психологічних умов і суспільних впливів під час оволодіння фітнес-технологіями. Включення студентів-першокурсників у навчально-виховний процес 3 фізичного виховання носить двосторонній характер: соціально-психологічна адаптація як форма оволодіння засобами фітнесу і як форма покращення здоров'я, пов'язана із залученням студентівпершокурсників до навчально-тренувальної діяльності (Круцевич\& Безверхня, 2010; Brooks \& Fahey, 1984).

Процес навчання у закладі вищої педагогічної освіти передбачає включення студентів у систему суспільних відносин і засвоєння соціальних цінностей суспільства, групи, норм поведінки. Студентство $€$ складовою частиною молоді, що характеризується особливими умовами життя, побуту та праці, суспільною поведінкою і психологією, системою ціннісних орієнтацій. Студентство потрібно розглядати як соціальну групу, яка має свою мету, свої специфічні особливості та готується до виконання соціальних функцій у суспільстві.

На студентський вік припадає процес активного формування соціальної зрілості, яка передбачає здатність студентів оволодіти необхідною сукупністю соціальних ролей, пізнавальних мотивів, інтересів до навчальних занять із фізичного виховання та фітнес-технологій. у студентів-першокурсників посилюється цілеспрямованість, рішучість, самостійність, індивідуальність, ініціативність у процесі навчальнотренувальної діяльності.

У цей час студенти-першокурсники удосконалюють оволодіння складнокоординаційними рухами, операціями аналізу та синтезу, теоретичного узагальнення. Для них стає властивим встановлення причиннонаслідкових зв'язків, систематичність, критичність, самостійна навчально-тренувальна діяльність. У юнацькому віці відбувається швидкий розвиток фізичних якостей, що пов'язані із різновидом навчальних занять і фітнес-програм. Характерним явищем у цей віковий період $\epsilon$ невмотивований ризик, невміння передбачити наслідки своїх дій.

Для юнацького віку характерне завершення процесу зростання, що приводить до нових можливостей, ролей, амбіцій, змінюються риси внутрішнього світу, самосвідомості, еволюціонують і перебудовуються психічні процеси, властивості особистості, змінюється емоційно-вольовий стан. Період ранньої дорослості $€$ найпродуктивнішим, найрезультативнішим i найбільш творчим періодом життя студентів, коли розкриваються потенційні можливості, завершується загальний соматичний розвиток органів і систем організму, статеве дозрівання, фізичний розвиток характеризується досягненням найвищих, “пікових" результатів, що базуються на всіх попередніх процесах біологічного, психологічного та соціального розвитку. Цей вік характеризується високим рівнем наукових, спортивних і професійних досягнень (Бохонкова, 2011; Carter т. ін.., 1982). 
Під час навчально-тренувальної діяльності студенти разом із викладачем здійснюють планування навчальних занять, застосування засобів фітнесу. Специфіка навчально-тренувальної сприяє формуванню життєвої позиції, яка здійснюється на фоні завершення фізичного розвитку. На цьому етапі домінантним $\epsilon$ становлення характеру й інтелекту, найбільша пластичність кори головного мозку, висока гнучкість в утворенні складних психомоторних навичок і рухів, найбільший обсяг запам'ятовування зорової і слухової модальності, високі показники уваги, найвища швидкість розв'язання поставлених тренувальних завдань; комплексний характер мисленнєвих операцій, висока емоційна чутливість до тренувальних ситуацій (Білецька, 2013).

У студентському віці відбувається становлення і стабілізація характеру, що особливо важливо під час навчально-тренувальної діяльності й освоєння повного спектру соціальних ролей дорослої людини. Із цим періодом пов'язаний початок “економічної активності”, під якою розуміємо включення студентів у самостійну професійну та навчально-тренувальну діяльність, створення сім'ї. Дослідники виділяють цей вік у якості центрального періоду становлення характеру й інтелекту студентів, формування мотивації, системи ціннісних орієнтацій, фізичних якостей. У цей період досягаються оптимуми розвитку інтелектуальної і фізичної снаги [Андрущенко, 2011; Левківська та ін., 2001; Плотнікова, 2001).

Умови навчально-тренувальної діяльності у закладі вищої педагогічної освіти вимагають від студентівпершокурсників уміння самостійної організації навчальної та тренувальної діяльності, тобто уміння вчитися. Необхідною умовою успішної навчально-тренувальної діяльності студентів-першокурсників $€$ засвоєння нових соціально-психологічних особливостей навчання. На першому курсі складається студентський колектив, формуються групи за інтересами, спеціальні знання, уміння та навички раціональної організації навчально-тренувальної діяльності, усвідомлюється (або не усвідомлюється) потреба до систематичних занять фізичною культурою і спортом, виробляється оптимальний режим праці, встановлюється система роботи із самоосвіти та самовиховання. Необхідною умовою навчально-тренувальної діяльності студентівпершокурсників із використанням засобів фітнесу є освоєння нових видів фітнес-програм і фітнес-технологій. Опанування нових методів і засобів навчально-тренувальної діяльності зменшує відчуття внутрішнього дискомфорту, блокує можливість конфлікту із суспільним середовищем, оточенням.

Висновки. Основними психолого-педагогічними умовами оптимізації навчально-виховного процесу 3 фізичного виховання, а також адаптації студентів-першокурсників до навчально-тренувальної діяльності 3 використанням засобів фітнесу в закладах вищої педагогічної освіти є розуміння викладачами 3 фізичного виховання особливостей адаптації студентів-першокурсників, тобто організація навчально-виховного процесу з урахуванням закономірностей вікового розвитку студентів-першокурсників до навчальнотренувальної діяльності, соціальних умов їхнього життя, озброєність викладачів із фізичного виховання науково обгрунтованою методикою вивчення й управління навчально-виховним процесом із застосуванням фітнес-технологій; уміння діагностувати та прогнозувати навчально-тренувальну діяльність студентів, впливати на неї 3 метою оптимізації навчально-виховного процесу 3 фізичного виховання; чітко регламентований відбір абітурієнтів і формування навчальних груп за інтересами, станом здоров'я, рівнем фізичної підготовленості до навчально-тренувальної діяльності; цілеспрямована організація виховної, спортивно-масової роботи зі студентами-першокурсниками щодо постійного розширення і поглиблення їх уявлень про нові форми, методи, засоби навчально-тренувалдьної діяльності, зокрема фітнес-технології; розвиток у студентів спеціальних знань, умінь і навичок; розвиток на всіх етапах навчально-тренувальної діяльності й у процесі познавчальної (секційної форми занять) мотиваційної складової; формування у студентів установки на самовиховання, самоосвіту, саморегуляцію до здоров'я та здорового способу життя, психологічної готовності до навчання і навчально-тренувальної діяльності; поступовість, послідовність і диференційованість у збільшенні фізичних навантажень, висунення навчальних вимог до студентівпершокурсників.

Перспективи подальших досліджень з даного напряму полягають у експериментальному обгрунтуванні методики застосування фітнес-технологій на заняттях із фізичного виховання студентів.

\section{Список використаних джерел}

Андрущенко В. П. Філософія і методологія розвитку вищої освіти України в контексті євроінтеграційних процесів : монографія / В. П. Андрущенко. - К. : Педагогічна думка, 2011. - 319 с.

Білецька В. В. Фізичне виховання. Оздоровчий фітнес : практикум / В. В. Білецька, І. Б. Бондаренко. - К. : НАУ. 2013. $-52 \mathrm{c}$

Бохонкова Ю. О. Соціально-психологічна адаптація першокурсників до умов вищих навчальних закладів : монографія / Ю. О. Бохонкова. - Луганськ, 2011. - 199 с.

Булатова М. М. Фитнес и двигательная активность : проблемы и пути решения / М. М. Булатова // Теорія і методика фізичного виховання і спорту. - 2007. - № 1. - С. 3-7.

Григорьев В. И. Стратегия формирования фитнес-индустрии : монография / В. И. Григорьев, В. С. Симонов. - СПб. : Изд-во СПбГУЭФ, 2006. - 208 с.

Жиденко А. О.Організація здоров'язбережувального освітнього середовища у вищих навчальних закладах / А. О. Жиденко. - Чернігів : ЧНПУ ім. Т. Г. Шевченка, 2012. - 44 с. 
Завійська В. М. Застосування сучасних оздоровчих технологій у навчально-виховному процесі фізичного виховання (для студентів вищих навчальних закладів III-IV рівнів акредитації) / В.М.Завійська, Л.В.Дмитренко, В. В. Іваночко. - Львів : Видавництво Львівської комерційної академії, 2015. - 160 с.

Зинченко В. Б. Фитнес-технологии в физическом воспитании : учеб. пособие / В. Б. Зинченко, Ю. О. Усачов. - К. : HAУ, 2011. $-152 \mathrm{c}$.

Иващенко Л. Я. Программирование занятий оздоровительным фитнесом $\quad / \quad$ Л. Я. Иващенко, $\quad$ А. Л. Благий, Ю. А. Усачев. - К. : Наук. світ, 2008. - 198 с.

Канішевський С. М. Науково-методичні та організаційні основи фізичного самоудосконалення студентства / С. М. Канішевський. - К. : ІЗМН, 1997. - 270 с.

Кібальник О. Я. Оздоровчі технології для підвищення рухової активності підлітків // Теорія та методика фізичного виховання і спорту. - 2007. - № 4. - С. 63-66.

Круцевич Т. Ю. Рекреація у фізичній культурі різних груп населення / Т. Ю. Круцевич, Г. В. Безверхня. - К. : Олімп. л-ра, 2010. -248 с.

Левківська Г. П. Адаптація першокурсників в умовах вищого закладу освіти : навчальний посібник / Левківська Г. П., Сорочинська В. С., Штифурак В. С. - К. : Либідь, 2001. -128 с.

Мачинська Н. І. Сучасні форми організації навчального процесу у вищій школі / Н. І. Мачинська, С. С. Стельмах. Л. : Львів держ. ун-т внутр. справ, 2012. - 179 с.

Плотнікова О. В. Важливість вивчення індивідуальних особливостей першокурсників у період дидактичної адаптації / О. В. Плотнікова // Рідна школа. - 2001. - № 10. - С. 62 - 64.

Присяжнюк С. І. Фізичне виховання [текст] : навчальний посібник для студентів вузів / С. І. Присяжнюк. - К. : Центр навчальної літератури, 2008. - 503 с.

Сайкина Е. Г. Фитнес в системе дошкольного и школьного физкультурного образования : диссертация ... доктора педагогических наук : 13.00.04 / Сайкина Елена Гавриловна. - Санкт-Петербург, 2009. - 560 с.

Сущенко О. Г. Теоретичні й практичні основи моделювання педагогічного процесу / О. Г. Сущенко. - Луганськ : ДЗ “ЛНУ імені Тараса Шевченка", 2010. - 176 с.

Томенко О. А. Неспеціальна фізкультурна освіта учнівської молоді: теорія і методологія: [монографія] / О. А. Томенко. - Суми : МакДен, 2012. - 276 с.

Усатова I. А. Сучасні фітнес-технології, як засіб виконання завдань 3 фізичного виховання для студентів 3 порушенням у стані здоров’я : навч.-метод. посіб. / І. А. Усатова, С. В. Цаподой. - Черкаси : ЧНУ імені Богдана Хмельницького, 2014.- 88 с.

Brooks, G. A. Exercise Physiology : Human Bioenergetics and its Applications / G. A. Brooks, T. D. Fahey. - New York : Wiley, 1984.

Carter J. E. L. Somatotypes of Monreal Olympic athletes / J. E. L. Carter, S. P. Aubry, D. A. Sleet. - NewYork : Karger, 1982.

Heckhausen H. Forderung der Lernmotivierung und der Intellektuellen Tuchtigkeiten. In : H. Koth : Regelung und Lernen. Stuttgart, 1969, S. 204.

\section{References}

Andrushchenko, V. P. (2011). Filosofiia i metodolohiia rozvytku vyshchoi osvity Ukrainy v konteksti yevrointehratsiinykh protsesiv: monohrafiia [Philosophy and methodology of higher education development in Ukraine in the context of european integration processes: monograph]. Kyiv: Pedahohichna dumka [in Ukrainian].

Biletska, V. V. (2013). Fizychne vykhovannia. Ozdorovchyi fitnes: praktykum [Physical Education. Health Fitness: Workshop]. Kyiv: NAU [in Ukrainian].

Bokhonkova, Yu. O. (2011). Sotsialno-psykholohichna adaptatsiia pershokursnykiv do umov vyshchykh navchalnykh zakladiv: monohrafiia [Socio-psychological adaptation of freshmen to the conditions of higher educational institutions: a monograph]. Luhansk [in Ukrainian].

Bulatova, M. M. (2007). Fitnes i dvigatelnaya aktivnost: problemyi i puti resheniya [Teoriia i metodyka fizychnoho vykhovannia i sportu]. Fitness and motor activity: problems and solutions [Theory and methodology of physical vihovannya i sports], № 1, 3-7 [in Russian].

Grigorev, V. I. (2006). Stratehyia formyrovanyia fytnes-yndustryy: monohrafyia [Strategy for the formation of the fitness industry: a monograph]. SPb.: Izd-vo SPbGUEF [in Russian].

Zhydenko, A. O. (2012). Orhanizatsiia zdorov'iazberezhuvalnoho osvitnoho seredovyshcha u vyshchykh navchalnykh zakladakh [Organization of healthcare-saving educational environment in higher educational institutions]. Chernihiv: ChNPU im. T.H. Shevchenka [in Ukrainian].

Zaviiska, V. M. (2015). Zastosuvannia suchasnykh ozdorovchykh tekhnolohii u navchalno-vykhovnomu protsesi fizychnoho vykhovannia (dlia studentiv vyshchykh navchalnykh zakladiv III-IV rivniv akredytatsii) [Application of modern healthimproving technologies in the educational process of physical education (for students of higher educational institutions of III-IV accreditation levels)]. Lviv: Vydavnytstvo Lvivskoi komertsiinoi akademii [in Ukrainian].

Zynchenko, V. B. (2011). Fytnes-tekhnolohyy v fyzycheskom vospytanyy: ucheb. posobye [Fitness technology in physical education: Textbook. Allowance]. Kyiv: NAU [in Russian].

Ivashchenko, L. Ya. (2008). Programmirovanie zanyatiy ozdorovitelnyim fitnesom [Programming of classes with healthimproving fitness]. Kyiv: Naukovyi svit [in Russian].

Kanishevs'kyy, S. M. (1997). Naukovo-metodychni ta orhanizatsiyni osnovy fizychnoho samoudoskonalennya studentstva [Methodological and organizational bases of physical self-improvement students]. Kyiv: IZMN [in Ukrainian]. 
Kibalnyk, O. Ya. (2007). Ozdorovchi tekhnolohii dlia pidvyshchennia rukhovoi aktyvnosti pidlitkiv [Teoriia ta metodyka fizychnoho vykhovannia i sportu]. Health-improving technologies for improving motor activity of adolescents [Theory and methods of physical education and sports], № 4, 63-66 [in Ukrainian].

Krutsevych, T. Yu. (2010). Rekreatsiia u fizychnii kulturi riznykh hrup naselennia [Recreation in the physical culture of different groups of the population]. Kyiv: Olimp. 1-ra [in Ukrainian].

Levkivska, H. P. (2001). Adaptatsiia pershokursnykiv v umovakh vyshchoho zakladu osvity: navchalnyi posibnyk [Adaptation of freshmen in the conditions of a higher educational institution: a manual]. Kyiv: Lybid [in Ukrainian].

Machynska, N. I. (2012). Suchasni formy orhanizatsii navchalnoho protsesu u vyshchii shkoli [Modern forms of organization of educational process in high school]. Lviv: Lviv derzh. un-t vnutr. sprav [in Ukrainian].

Plotnikova, O. V. (2001). Vazhlyvist vyvchennia indyvidualnykh osoblyvostei pershokursnykiv u period dydaktychnoi adaptatsii [Ridna shkola]. The importance of studying the individual characteristics of the first-year students in the period of didactic adaptation [Native school], № 10. - C. 62-64 [in Ukrainian].

Prysyazhnyuk, S. I. (2008). Fizychne vykhovannya [tekst]: navchal'nyy posibnyk dlya studentiv vuziv [Physical education [text]: a textbook for university students]. Kyiv: Tsentr navchal'noyi literatury [in Ukrainian].

Saykina, E. G. (2009). Fitnes v sisteme doshkolnogo i shkolnogo fizkulturnogo obrazovaniya (dis ... dokt. ped. nauk: 13.00.04) [Fitness in the system of preschool and school physical education [PhD thesis)]. Sankt-Peterburg [in Russian].

Sushchenko, O.H. (2010). Teoretychni y praktychni osnovy modeliuvannia pedahohichnoho protsesu [Teoretychni y praktychni osnovy modeliuvannia pedahohichnoho protsesu]. Luhansk: DZ "LNU imeni Tarasa Shevchenka" [in Ukrainian].

Tomenko, O. A. (2012). Nespetsialna fizkulturna osvita uchnivskoi molodi : teoriia i metodolohiia: [monohrafiia] [Nonspecific physical education of students: theory and methodology: [monograph]. Sumy: MakDen [in Ukrainian].

Usatova, I. A. (2014). Suchasni fitnes-tekhnolohii, yak zasib vykonannia zavdan z fizychnoho vykhovannia dlia studentiv z porushenniam u stani zdorovia: navch.-metod. posib. [Modern fitness technology as a means of performing physical education tasks for students with a disorderly condition: a teaching method. manual.]. Cherkasy: ChNU imeni Bohdana Khmelnytskoho [in Ukrainian].

Brooks, G. A. (1984). Exercise Rhysiology: Human Bioenergetics and its Applications. New York: Wiley [in English].

Carter, J. E. L. (1982). Somatotypes of Monreal Olympic athletes. NewYork: Karger [in English].

Heckhausen, H. (1969). Forderung der Lernmotivierung und der Intellektuellen Tuchtigkeiten. In: H. Koth: Regelung und Lernen. Stuttgart [in Deutsch].

\section{ZHAMARDIY V.}

Ukrainian Medical Stomatological Academy, Poltava, Ukraine

\section{FEATURES OF SOCIO-PSYCHOLOGICAL ADAPTATION OF FIRST YEAR STUDENTS FOR EDUCATIONAL TRAINING WITH USAGE OF FITNESS}

The article deals with the problem of socio-psychological adaptation of freshmen students to training activities using fitness equipment. It was clarified that the concept of social and psychological adaptation can be considered as a process of adaptation of freshmen students to the new conditions of teaching and training activities in the institution of higher pedagogical education, entering the cultural and educational environment, mastering its norms, developing a model of behavior and training activities. It is determined that socio-psychological adaptation of first-year students at the initial stages of educational activity caused by a number of regular features and is characterized by a large volume of material, high level of self-dependence and responsibility. The greatest difficulties are in changing the social position of first-year students during the transition from the school community, methods and means of training activities, relationships and stereotypes of their behavior. It is proved that one of the most effective organizational mechanisms for ensuring successful adaptation of students for training activities using fitness means is social and psychological adaptation, which unites the physical education teachers' efforts. The main forms of training activities should be trainings, round tables, attracting students to active training and competitive activities while studying at a higher educational institution.

Key words: adaptation, age features, educational activity, first-year students, physical education, fitness, fitness technology.

Стаття надійшла до редакції 12.04. 2018 р. 